\title{
Effect of nano fertilization on sugar beet
}

\author{
A. M. Hassnein, M. A. Azab, M. A. El-Hawary * and N. N. Darwish \\ Agronomy Department, Faculty of Agriculture, Al-Azhar University, Cairo, Egypt \\ * Corresponding author E-mail: Alhawary20g@azhar.edu.eg (M. El-Hawary).
}

\begin{abstract}
ABSRTRACT
Sugar beet (Beta vulgaris L.) ranks second important sugar crop in the world. The aim of the herein trial is to study the effect of mineral and nano-nitrogen fertilizer (Sissay) and a mix of three micro elements (boron, zinc and manganese) on growth and yield in sugar beet plants. Two greenhouse experiments were carried out at the experimental farm of the Faculty of Agriculture, Nasr city, Al-Azhar University, Cairo, Egypt during 2016/2017 and 2017/2018 seasons. The experiments were laid out in a complete randomized block design with four replications. The obtained results showed that the treatment had mineral nitrogen at a rate of 54 or $90 \mathrm{Kg} N$ per feddan + nano Sissay $(810 \mathrm{~g} /$ feddan $)+$ a mix of nano micro elements $(200 \mathrm{ppm})$ gave the highest values of relative growth rate, net assimilation rate over 60 to 90 days from sowing date, root weight, sucrose percentage and sugar yield per plant at harvest time as compared with all other studied treatments in both seasons. Control treatment (without fertilization) gave the lowest values. In conclusion, using nano-nitrogen fertilizer (Sissay) and micronutrients (B, Zn and Mn) with mineral nitrogen fertilizer can save around $40 \%$ from recommended doses of mineral nitrogen fertilizer.
\end{abstract}

Keywords: Nanofertilization; Sugar beet; Nitrogen fertilization.

\section{INTRODUCTION}

Sugar beet (Beta vulgaris L.) ranks as the second important sugar crop in the world. The great importance of sugar beet crop is not only from its ability to grow in the newly reclaimed areas as economic crop, but also for production of higher sugar yield under these conditions as compared with sugar cane. Also, its productivity makes it a good cash crop at this situation. There are many attempts to increase sugar beet productivity and quality. This increase is likely to be obtained by growing sugar beet crop in newly reclaimed soils and increased productivity of unit area. Increasing sugar beet production can be achieved through applying the optimizing agricultural practices i.e,. fertilization and cultivating high yielding varieties.

Recently, nanotechnology represents a new frontier for the research community. Nanotechnology works with the smallest possible particles which raise hopes for improving agricultural productivity through encountering problems unsolved conventionally. In the management aspects, efforts are made to increase the efficiency of applied fertilizers with the help of nano fertilization clays and zeolites and restore soil fertility by releasing fixed nutrients.

Jakiene et al. (2015), reported that bioorganic nano fertilizer at single 1 liter per hectare dose in sugar beet plants increased root biomass by $42.6 \%$, net photosynthetic productivity by $15.8 \%$, root yield by $12.6 \%$, sucrose content by $1.03 \%$ and yield of white sugar by $19.2 \%$ in comparison with the untreated beets. Liu and Lal (2015) reported that the application of nano particles to sugar beet plants can be beneficial for growth and development due to its ability for greater absorbance and high reactivity. Barlog et al (2016) reported that utilization of micronutrient like manganese, zinc and iron with balance can enhance and increase productivity of sugar beet yield. Mekdad and Rady (2016) showed that adding micronutrient mixtures $(\mathrm{Fe}+\mathrm{Zn}+\mathrm{Mn})$ improved yield and its attributes of sugar beet crop. Dewdar et al. (2018) found that the best results were obtained when sugar beet plants were treated with nano-microelements $200 \mathrm{mg} / \mathrm{L}+$ urea $1 \%$ and ranked as the first favorable treatment for root length and diameter, dry matter per plant as root, top and sugar yields in both seasons.

However, in Egypt there are few investigations concerning applying nano fertilizers on sugar beet plants, Therefore, this investigation was carried out to study the effect of mineral and nano nitrogen fertilizer (Sissay) and a mix of three micro elements (boron, zinc and manganese) on s growth and yield of sugar beet plants (Beta vulgaris L.) variety Gloria.

\section{MATERIALS AND METHODS}

Two cement lysimeter experiments were carried out at the greenhouse at the Experimental Farm in Faculty of Agriculture, Al-Azhar University, Nasr City, Cairo, Egypt, 
during 2016/2017 and 2017/2018 seasons to study the effect of mineral and nano nitrogen fertilizer (Sissay) and a mix of three microelements (boron, Zinc and Manganese) on growth and yield of sugar beet plants (Beta vulgaris L. ) variety Gloria.

The experiment treatments were as follows:

Control (foliar spraying with tap water).

Adding nitrogen fertilizer (top dressing) at the rate of $54 \mathrm{~kg} \mathrm{~N} / \mathrm{fed}$. (60\% of the recommended amount).

Adding nitrogen fertilizer (top dressing) at the rate of $90 \mathrm{~kg} \mathrm{~N} / \mathrm{fed}$. (100\% of the recommended amount).

Foliar Spraying with Sissay (nano nitrogen fertilizer) at a rate of $810 \mathrm{~g} / \mathrm{fed}$.

Foliar Spraying with mixed micro elements (boron, zinc and manganese) at a concentration of $200 \mathrm{ppm} / \mathrm{fed}$.

Adding nitrogen fertilizer (top dressing) at the rate of $54 \mathrm{~kg} \mathrm{~N} / \mathrm{fed}+$ foliar spraying with mixed micro elements ( $\mathrm{B}, \mathrm{Zn}$ and $\mathrm{Mn}$ ) at a concentration of $200 \mathrm{ppm} / \mathrm{fed}$.

Adding nitrogen fertilizer (top dressing) at the rate of $90 \mathrm{~kg} \mathrm{~N} / \mathrm{fed}+$ foliar Spraying with mixed micro elements (B, $\mathrm{Zn}$ and $\mathrm{Mn}$ ) at a concentration of $200 \mathrm{ppm} / \mathrm{fed}$.

Foliar Spraying with Sissay (nano nitrogen fertilizer) at a rate of $810 \mathrm{~g} / \mathrm{fed}+$ foliar spraying with mixed micro elements (B, Zn and $\mathrm{Mn}$ ) at a concentration of $200 \mathrm{ppm} / \mathrm{fed}$.

Adding nitrogen fertilizer (top dressing) at the rate of $54 \mathrm{~kg} \mathrm{~N} / \mathrm{fed}+$ foliar spraying with Sissay (nano nitrogen fertilizer) at a rate of $810 \mathrm{~g} / \mathrm{fed}$.

Adding nitrogen fertilizer (top dressing) at the rate of $90 \mathrm{~kg} \mathrm{~N} 2 / \mathrm{fed}$. + foliar spraying with Sissay (nitrogen nano-fertilizer) at a rate of $810 \mathrm{~g} / \mathrm{fed}$.

Adding nitrogen fertilizer (top dressing) at the rate of $54 \mathrm{~kg} \mathrm{~N} / \mathrm{fed}$. + foliar spraying with Sissay (nitrogen nano-fertilizer) at a rate of $810 \mathrm{~g} /$ fed. + foliar spraying with mixed micro elements (B, Zn and $\mathrm{Mn}$ ) at a concentration of $200 \mathrm{ppm} / \mathrm{fed}$.

Adding nitrogen fertilizer (top dressing) at the rate of $90 \mathrm{~kg} \mathrm{~N} /$ fed. + Foliar spraying with Sissay (nano nitrogen fertilizer) at a rate of $810 \mathrm{~g} / \mathrm{fed}$. + Foliar spraying with mixed micro elements (B, $\mathrm{Zn}$ and $\mathrm{Mn})$ at a concentration of $200 \mathrm{ppm} / \mathrm{fed}$.
The experiments were laid out in a completely randomized block design with four replications for each treatment

The cement lysimeter dimensions of average $(50 \mathrm{~cm}$ width $) \times(40 \mathrm{~cm}$ length $) \times 40 \mathrm{~cm}$ deep were filled with $17 \mathrm{~kg}$ soil (air dried). Organic fertilization as compost, supper phosphate $\left(15.5 \% \mathrm{P}_{2} \mathrm{O}_{5}\right)$ and potassium sulfate $\left(48 \% \mathrm{~K}_{2} \mathrm{O}\right)$ fertilizations were added at the recommended doses and mixed with the soil before filling the lysimeter and planting. The mechanical and chemical analyses of the experimental soil were determined and presented in Table (1). Sissay (nitrogen nanofertilizer) is made of very fine crushed calcite minerals of sedimentary origin such as marine algae and fossilized ammonite. The calcite decomposed in microwave tirbomecanica with new technology, as new technology in formation of nano dots. The calcite mineral which has been added to zeolite minerals and spiraling algae. It is combination of minerals, zeolite calcite minerals, and delicate microenhilados with the supplement of dried extracts of nettle plants. The chemical analyses of Sissay are presented in Table (2). Nitrogen fertilizer in the form of Urea $(46 \% \mathrm{~N})$. Boron, zinc and manganese were mixed and added as solution at concentration of 200 ppm.Then, they were sprayed in 50 and 70 days from sowing date $(200 \mathrm{~L} / \mathrm{fed})$. The seeds of sugar beet variety Gloria were obtained from Agriculture Research Centre (A.R.C.). Twenty seeds were planted on December $25^{\text {th }}$ in each lysimeter in the two seasons at the depth of 2 $\mathrm{cm}$, after 30 days from sowing date the plants were thinned to six plants per lysimeter. The second thinning was performed after 40 days as the plants were thinned to three plants per lysimeter.

\section{Data recorded}

Two samples were taken after 60 and 90 days from sowing date to measure the following data:

\section{Growth attributes}

Relative growth rate (RGR): It was calculated according to the following formula (Watson 1958).

$$
\text { RGR = Loge W2- Loge W1 / T2-T1 (g/week) }
$$

Net assimilation Rate (NAR): It was calculated according to the following formula (Watson 1958).

$\mathrm{NAR}=(\mathrm{W} 2-\mathrm{W} 1) \quad($ LogeA2- Loge $\mathrm{A} 1) /(\mathrm{T} 1-\mathrm{T} 2)$ (A2-A1) $\left(\mathrm{g} / \mathrm{m}^{2} /\right.$ week $)$ 
Whereas: W1 and W2 refer to dry plant weight at first time $\mathrm{T} 1$ and second time $\mathrm{T} 2$ in days, respectively, A1 and A2 refer to leaf area at first time. T1 and second time T2, respectively.

\section{Yield characters}

The plants were harvested after 180 days from sowing date and the following data were determined.

\section{Root fresh weight ( $g$ )}

\section{Sucrose percentage in roots}

It was determined by using Saccharometer.

\section{Sugar Yield per plant $(g)$}

It is calculated as a percentage of sucrose $x$ root fresh weight.

Data were statistically analyzed according to the technique of analysis of variance (ANOVA) and the least significant difference (LSD) method was used to test the difference among the treatment means as published by Gomez and Gomez (1984).

\section{RESULTS AND DISCUSSION}

\section{Relative growth rate (g/day)}

Average relative growth rate (g/day) at $60-$ 90 days period from sowing date of sugar beet as affected by nitrogen, sissay and micro elements (boron, zinc and manganese) fertilization treatments in 2016/2017 and 2017/2018 seasons are shown in (Table 3).

Results recorded in Table 3 show clearly that relative growth rate (g/day) at $60-90$ days period from sowing date significantly affected by nitrogen, Sissay and micro elements (boron, zinc and manganese) fertilization treatments in 2016/2017 and 2017/2018 seasons .Sugar beet plants received nitrogen fertilizer at the rate of $90 \mathrm{~kg} \mathrm{~N} /$ feddan surpassed control by 3.91 and $5.24 \%$, nitrogen fertilizer at a rate of $54 \mathrm{kgN} /$ feddan by 2.14 and $3.57 \%$, Sissay by 5.29 and $8.75 \%$ as well as micro elements treatment by 3.02 and $11.6 \%$ in relative growth rate (g/day) at 60 -90 days from sowing date in 2016/2017 and 2017/2018 seasons, respectively . On the other hand, sugar beet plants treated with nitrogen $(90 \mathrm{~kg} / \mathrm{feddan})+$ Micro nutrients exceeded control in relative growth rate (g/day) by 4.78 and $7.26 \%$, nitrogen fertilizer at the rate of $90 \mathrm{~kg} \mathrm{~N} /$ feddan by 0.84 and 1.92 $\%$ as well as micro elements by 3.88 and 13.19 $\%$ in 2016/2017 and 2017/2018 seasons, respectively. Whilesugar beet plants treated with nitrogen $(90 \mathrm{~kg} / \mathrm{feddan})+$ Sissay increased relative growth rate (g/day) than those grown under the control by 5.65 and 8.06 $\%$, nitrogen fertilizer at the rate of $90 \mathrm{~kg}$ $\mathrm{N} /$ feddan by 1.67 and $2.68 \%$ and plants treated with sissay alone by 7.05 and $11.67 \%$ in 2016/2017 and 2017/2018 seasons , respectively.

The obtained results show that applied nitrogen at a rate of $90 \mathrm{~kg} \mathrm{~N} /$ fed. + Sissay + micro nutrients was the best treatment whereas it gave the highest relative growth rate at 60 - 90 days period from sowing date 0.252 and $0.278 \mathrm{~g} /$ day compared to all other treatments in 2016/2017 and 2017/2018 seasons, respectively. This treatment increased relative growth rate (g/day) at 60 - 90 days period from sowing date over those of the control by 9.57 and $12.10 \%$, plants fertilized by $90 \mathrm{~kg} \mathrm{~N} / \mathrm{fed}$. By 5.44 and $6.51 \%$, Sissay treatment by 11.01 . And $15.83 \%$ as well as micro elements treatment by 8.62 and $18.30 \%$ in 2016/2017 and $2017 / 2018$ seasons, respectively. This treatment followed by added nitrogen at $54 \mathrm{~kg} \mathrm{~N} / \mathrm{fed}$. + Sissay + micro elements which gave 0.249 and 0.271 g/day in 2016/2017 and 2017/2018 seasons, respectively. The different in relative growth rate $(\mathrm{g} /$ day) between nitrogen at a rate of 54 and $90 \mathrm{~kg} \mathrm{~N} / \mathrm{fed}$. + Sissay + micronutrients were significant as compared with all other treatments in both seasons.

These results suggested that combined Sissay and micro elements with nitrogen increased utilization of nitrogen by sugar beet plants which led raising relative growth rate and production also may be saved $36 \mathrm{~kg}$ $\mathrm{N} /$ feddan.

The increase in relative growth rate according to treated sugar beet plants by nitrogen plus Sissay+ micro nutrients may be attributed to the encouragement growth and increasing total plant weight during growth period of 60 -90 days from sowing date which led to raising relative growth rate, These results are in agreement with those of Jakiene et al. (2015).

\section{Net assimilation rate $\left(\mathrm{mg} / \mathrm{cm}^{2} /\right.$ week $)$}

Average net assimilation rate $(\mathrm{mg} / \mathrm{cm} 2 /$ week) at $60-90$ days from sowing date of sugar beet as affected by nitrogen, Sissay and micro elements (boron, zinc and manganese) fertilization treatments in 2016/2017 and 2017/2018 seasons are shown in Table (3). Results recorded in Table (4) show clearly that net assimilation rate $\left(\mathrm{mg} / \mathrm{cm}^{2} /\right.$ week) at (60-90) days period from sowing date significantly affected by nitrogen, 
Sissay and micro elements (boron, zinc and manganese) fertilization treatments in 2016/2017 and 2017/2018 seasons . the lowest net assimilation rate 0.10 and $0.28 \mathrm{mg} / \mathrm{cm}^{2} /$ week was recorded when sugar beet plants grown under the control (without fertilization) as compared with all other treatments at (6090) days period from sowing date in $2016 / 2017$ and 2017/2018 seasons, respectively.

Sugar beet plants received nitrogen fertilizer at the rate of $90 \mathrm{~kg} \mathrm{~N} / \mathrm{fed}$. with micro elements surpassed control by 910.00 and $178.57 \%$, while added nitrogen fertilizer at a rate of (90 kg N/fed) with Sissay exceeded control by 760.00 and $339.29 \%$, Sissay by 5.29 and $8.75 \%$ in net assimilation rate $(\mathrm{mg} /$ $\mathrm{cm}^{2} /$ week) at (60-90) days period from sowing date in 2016/2017 and 2017/2018 seasons, respectively. The results show also that sugar beet plants treated with nitrogen $(90 \mathrm{~kg} \mathrm{~N} / \mathrm{fed}$.) + Sissay + micro nutrients exceeded control in net assimilation rate by 1360.00 and $360.71 \%$, nitrogen fertilizer at the rate of (90 kg N/fed.) by 111.59 and $143.40 \%$, Sissay by 210.63 and $168.75 \%$ as well as micro elements by 711.11 and $230.77 \%$ at (60-90) days period from sowing date in 2016/2017 and 2017/2018 seasons, respectively.

These results show clearly that combined Sissay and micro elements with nitrogen at the rate of $90 \mathrm{~kg} \mathrm{~N} / \mathrm{fed}$. gave the highest net assimilation rate as compared with all other treatments. These results might be attributed to enhancement photosynthetic rate and decreased plant respiration rate, therefore raising net assimilation rate. These results are in harmony with Jakiene et al. (2015) and Mekdad and Rady (2016).

\section{Root fresh weight at harvest}

Average root fresh weight (g) of sugar beet at harvest time as affected by nitrogen, Sissay and micro elements (boron, zinc and manganese) fertilization treatments in $2016 / 2017$ and 2017/2018 seasons are shown in Table (3). Results recorded in Table 3 show that all treatments significantly increased root fresh weight compared to the control. Sugar beet plants received nitrogen fertilizer at the rate of $90 \mathrm{~kg} \mathrm{~N} / \mathrm{fed}$. Surpassed control by 207.69 and $204.47 \%$, nitrogen fertilizer at a rate of $54 \mathrm{~kg} \mathrm{~N} /$ fed. by 15.44 and $18.08 \%$, Sissay by 22.52 and $17.98 \%$ as well as micro elements treatment by 29.03 and $35.78 \%$ in root fresh weight at harvest in 2016/2017 and 2017/2018 seasons, respectively. While fertilized sugar beet plants with $54 \mathrm{~kg} \mathrm{~N} / \mathrm{fed}$. Increased root fresh weight by 166.52 and 158.10 compared to those of the control in 2016/2017 and 2017/2018 seasons, respectively. In this connection, spraying sugar beet plants by Sissay as a nano substance increased root fresh weight at harvest by 166.52 and $158.10 \%$ compared to those of the control in 2016/2017 as well as $2017 / 2018$ seasons, respectively. Also treated sugar beet plants with mixed nano micro elements (boron, zinc and manganese) caused 138.46 and $120.95 \%$ increase in root fresh weight at harvest compared to those of the control in 2016/2017 as well as 2017/2018 seasons, respectively.

The results showed also that, sugar beet plants treated with nitrogen (90 kg/feddan) + Micro nutrients exceeded control in root fresh weight at harvest by 228.51 and 274 in season 2016/2017 and 2017/2018, while nitrogen fertilizer at the rate of (90 kg N/fed.) by 6.76 and $22.81 \%$ as well as micro elements by 37.76 and $69.40 \%$ in 2016/2017 and 2017/2018 seasons, respectively. While sugar beet plants treated with nitrogen (90 kg/fed.) + Sissay increased root fresh weight at harvest than those grown under the control by 266.97 and $371.43 \%$, nitrogen fertilizer at the rate of $90 \mathrm{~kg}$ $\mathrm{N}$ / fed. by 19.26 and $54.69 \%$ and plants treated with Sissay alone by 46.13 and $85.39 \%$ in 2016/2017 and 2017/2018 seasons, respectively.

The obtained results show that applied nitrogen at a rate of $90 \mathrm{~kg} \mathrm{~N} /$ fed. + Sissay + micronutrients gave the highest root fresh weight at harvest 1081 and $1190 \mathrm{~g}$ compared to all other treatments in 2016/2017 and 2017/2018 seasons, respectively. This treatment raising root fresh weight at harvest than those of the control by 389.14 and $466.67 \%$, plants fertilized with $90 \mathrm{~kg} \mathrm{~N} /$ fed. by 58.97 and 85.93 $\%$, Sissay treatment by 94.77 and $122.85 \%$ as well as micro elements treatment by 105.12 and $156.47 \%$ in 2016/2017 and 2017/2018 seasons, respectively. This treatment followed by added nitrogen at $54 \mathrm{~kg} \mathrm{~N} /$ fed. + Sissay + micro-elements which gave 1070 and $1180 \mathrm{gm}$ in 2016/2017 and 2017/2018 seasons, respectively. The different in root fresh weight at harvest between applied nitrogen at a rate of 54 or $90 \mathrm{~kg} \mathrm{~N} /$ fed. + Sissay + micronutrients were insignificant and were significant compared to all other treatments in both seasons.

The increase in root fresh weight according to fertilizing sugar beet plants with nitrogen at the rate of $90 \mathrm{~kg} \mathrm{~N} /$ feddan plus Sissay and micro elements may be attributed to the favourable effect of this treatment on net assimilation rate and relative growth weight 
(Table 3), which led to raising root fresh weight. These results are in harmony with those obtained by Jakiene et al. (2015) and Mekdad and Rady (2016).

\section{Sucrose percentage}

Average sucrose percentage of sugar beet at harvest time as affected by nitrogen, Sissay and micro elements (boron, zinc and manganese) fertilization treatments in 2016/2017 and 2017/2018 seasons are shown in Table (4). Results recorded in Table (4) show that sucrose percentage at harvest date significantly affected by nitrogen, Sissay and micro elements (boron, zinc and manganese) fertilization treatments in 2016/2017 and 2017/2018 seasons .Sugar beet plants did not received nitrogen fertilizer (control) gave the highest sucrose percentage 20.39 and $20.49 \%$ followed by plants treated by micro elements 20.06 and $20.16 \%$ compared to all other treatments in 2016/2017 and 2017/2018 seasons, respectively. While fertilized sugar beet plants with $90 \mathrm{~kg} \mathrm{~N} /$ feddan gave the lowest sucrose percentage 17.09 and $17.04 \%$ compared to all other treatments in 2016/2017 and 2017/2018 seasons, respectively.

The differences in sucrose percentage were insignificant between Sissay, nitrogen (54 kg N/fed.) + Micro nutrients, Sissay + Micro nutrients, nitrogen (54 kg N/fed) + Sissay, nitrogen (90 kg N/fed.) + Sissay, nitrogen (54 $\mathrm{kg} \mathrm{N} /$ fed.) + Sissay + Micro nutrients and nitrogen (90 kg N/fed.) + Sissay + Micro nutrients treatments in both seasons.

The increase in sucrose percentage under the unfertilized (control) sugar beet plants may be attributed to the sugar beet plants grown without receiving fertilizers had the lowest net assimilation rate (Table 3 ) as well as according to the fact that sugar beet plants had the negative correlation between root volume and sucrose percentage, therefore increased concentration of sucrose. These results are in harmony with those of Jakiene et al. (2015) and Dewdar et al. (2018).

\section{Sugar yield per plant}

Average sugar yield per plant (g) of sugar beet at harvest time as affected by nitrogen, Sissay and micro elements (Boron, Zinc and Manganese) fertilization treatments in 2016/2017 and 2017/2018 seasons are shown in (Table 4). Results recorded in (Table 4) show that sugar yield per plant at harvest date. significantly affected by nitrogen, Sissay and micro elements (boron, zinc and manganese) fertilization treatments in 2016/2017 and
2017/2018 seasons. sugar beet plants received nitrogen fertilizer at the rate of $90 \mathrm{~kg} \mathrm{~N} / \mathrm{fed}$. surpassed control by 150.64 and $153.45 \%$, nitrogen fertilizer at a rate of $54 \mathrm{~kg} \mathrm{~N} / \mathrm{fed}$. by 4.02 and $14.28 \%$, Sissay by 9.61 and $9.16 \%$ as well as micro elements treatment by 9.69 and $16.59 \%$ in sugar yield per plant in 2016/2017 and 2017/2018 seasons, respectively. While fertilized sugar beet plants with $54 \mathrm{~kg} \mathrm{~N} /$ fed. increased sugar yield per plant by 140.96 and $121.57 \%$ compared to the control in 2016/2017 and 2017/2018 seasons, respectively. In this connection, spraying sugar beet plants with Sissay as a nano fertilizer increased sugar yield per plant by 1128.67 and $131.49 \%$ compared to those of the control in 2016/2017 as well as 2017/2018 seasons, respectively. Also treated sugar beet plants with mixed nano fertilizer and micro-elements (Boron, Zinc and Manganese) caused 134.93 and $117.38 \%$ increase in sugar yield per plant as compared with those of the control in 2016/2017 as well as 2017/2018 seasons, respectively. On the other hand, sugar beet plants treated with nitrogen (90 N kg/fed) + micro nutrients exceeded control in sugar yield per plant by 189.60 and $227.52 \%$, nitrogen fertilizer at the rate of $90 \mathrm{~kg} \mathrm{~N} / \mathrm{fed}$. by 15.54 and $29.22 \%$ as well as micro elements by 23.27 and $50.66 \%$ in 2016/2017 and 2017/2018 seasons, respectively. While sugar beet plants treated with nitrogen $(90 \mathrm{~N} \mathrm{~kg} / \mathrm{fed})+$ Sissay increased sugar yield per plant than those grown on the control by 240.09 and $308.83 \%$, nitrogen fertilizer at the rate of $90 \mathrm{~kg} \mathrm{~N} / \mathrm{fed}$. by 35.69 and $61.31 \%$ and plants treated with Sissay alone by 48.73 and $85.3976 .08 \%$ in 2016/2017 and 2017/2018 seasons, respectively.

The obtained results show that applied nitrogen at a rate of $90 \mathrm{~kg} \mathrm{~N} /$ fed. + Sissay + micro nutrients was the best treatment because it gave the highest sugar yield per plant (202.04 and $229.67 \mathrm{~g}$ ) compared to all other treatments 2016/2017 and 2017/2018 seasons, respectively. This treatment raised sugar yield per plant than those of the control by 348.98 and $433.74 \%$, plants fertilized with $90 \mathrm{~kg}$ $\mathrm{N} /$ fed. by 79.13 and $110.59 \%$, Sissay treatment by 96.35 and $129.88 \%$ as well as micro elements treatment by 91.11 and $145.53 \%$ in 2016/2017 and 2017/2018 seasons, respectively. This treatment followed by adding nitrogen at $54 \mathrm{~kg} \mathrm{~N} /$ fed. + Sissay + micro elements which gave 201.69 and $228.92 \mathrm{~g}$ in 2016/2017 and 2017/2018 seasons, respectively. The different in sugar yield per plant between applied nitrogen at a rate of $90 \mathrm{~kg} \mathrm{~N} / \mathrm{fed}$. + Sissay + micronutrients and added nitrogen at the rate 
of $54 \mathrm{~kg} \mathrm{~N} /$ fed. + Sissay + micro elements was insignificant and was significant as compared with all other treatments in both seasons.

The highest root fresh weight under the application of nitrogen at the rate of $90 \mathrm{~kg}$ N/fed. plus Sissay and micro elements may be attributed to their effect on increasing relative growth rate, net assimilation rate (Table 3), these treatment gave the highest root yield per plant (Table 3), These results are in harmony with those of Jakiene et al. (2015) and Dewdar et al. (2018).

\section{Conclusion}

Generally it could be recommended that using nano nitrogen fertilizer (Sissay) and micronutrients (B, $\mathrm{Zn}$ and $\mathrm{Mn}$ ) with mineral nitrogen fertilizer can save $40 \%$ from recommended dose of mineral nitrogen fertilizer without insignificant differences in root and sugar yield per plant of sugar beet plants under greenhouse conditions of Cairo

\section{REFERENCES}

Barlog, P., Nowacka, A., Blaszyk, R., 2016.Effect of zinc band application on sugar beet yield, quality and nutrient uptake. Plant Soil Environ. 62 (1), 30-35.

Dewdar, M.D.H., Abbas, M.S., El-Hassanin, A.S., Abdel-Aleem, H.A., 2018. Effect of nano Micronutrients and nitrogen foliar applications on sugar beet (Beta vulgaris L.) of quantity and quality traits in marginal soils in Egypt. J. Curr. Microbiol. Appl. Sci., 7 (8), 4490-4498.
Gomez, K.A., Gomez, A.A., 1984. Statistical Procedures for Agricultural Research. 2nd Ed., John Wiley \& sons, West Sussex, UK.

Jakienè, E., Spruogis, V., Romaneckas, K., Dautartè, A., avižienytė, D., 2015. The bioorganic nano fertilizer improves sugar beet photosynthesis process and productivity. Zemdirbyst., 102, 141-146.

Liu, R., Lal, R., 2015. Potentials of engineered nanoparticles as fertilizers for increasing agronomic productions. A review. Sci. Total Envir., 514, 131-139.

Mamyandi, M.M, Pirzad, A., Zardoshti, M.R., 2012. Effect of Nano-iron spraying at varying growth stage of sugar beet (Beta vulgaris L.) on the size of different plant parts. J. Agric. Crop Sci., 14 (12), 740-745

Mekdad, A.A., Rady, M.M., 2016. Response of Beta vulgaris L. to nitrogen and micronutrients in dry environment. Plant Soil Environ., 62 (1), 23-29.

Page, A.L., Miller, R.H., Keeny, D.R., 1982. Methods of Soil Analysis (Part 2). In: Chemical and Microbiological Properties. Agron, vol. 9. SSSA, Madison.

Qaswar, M., Hussain, S., Rengel, Z., 2017. Zinc fertilisation increases grain zinc and reduces grain lead and cadmium concentrations more in zinc-biofortified than standard wheat cultivar. Sci. Total Environ., 605, 454-460. Watson, D.J., 1958. The dependence of net assimilation rate on leaf area index. Ann. Bot. London, N.S. 22, 37- 45.

Table 1. Mechanical and chemical properties of the experiment soil in 016/2017 and 2017/2018 seasons.

\begin{tabular}{ccc}
\hline \multirow{2}{*}{ Item } & \multicolumn{2}{c}{ Seasons } \\
\cline { 2 - 3 } Mechanical properties & $2016 / 17$ & $2017 / 18$ \\
Sand & & \\
Silt & 14.27 & 13.44 \\
Clay & 22.31 & 22.76 \\
& 63.42 & 63.80 \\
Soil texturae class & Clay & Clay \\
Chemical properties & & \\
PH & 7.12 & 6.98 \\
Ec & 2.07 & 2.14 \\
Organic matter\% & 1.96 & 2.02 \\
N ppm & 22.30 & 23.03 \\
P ppm & 7.20 & 6.90 \\
K ppm & 27.27 & 28.00 \\
\hline
\end{tabular}


Table 2. Sissay fertilizer chemical component.

Chemical content $\%$

\begin{tabular}{ccccccc}
\hline $\mathrm{CaCO}_{3}$ & $\mathrm{MnO}$ & $\mathrm{SiO}_{2}$ & $\mathrm{P}$ & $\mathrm{K}$ & $\mathrm{S}$ & Organic N \\
35.00 & 1.90 & 11.10 & 0.28 & 0.10 & 0.52 & 15 \\
\hline
\end{tabular}

Table 3. Average relative growth rate(g/week), net assimilation rate (g/week) and root fresh weight ( $g$ ) at 60 -90 days from sowing (DFS) at harvest date as affected by nitrogen, Sissay and mixed micro elements (B, Zn and Mn) in 2016/2017 and 2017/2018 seasons.

\begin{tabular}{|c|c|c|c|c|c|c|}
\hline \multirow[t]{2}{*}{ Fertilization treatments } & \multicolumn{2}{|c|}{$\begin{array}{l}\text { Relative growth rate } \\
\text { (g/week) at } 60-90 \text { DFS }\end{array}$} & \multicolumn{2}{|c|}{$\begin{array}{l}\text { Net assimilation rate } \\
\text { (g/week) at } 60-90 \text { DFS }\end{array}$} & \multicolumn{2}{|c|}{$\begin{array}{l}\text { Root fresh weight }(\mathrm{g}) / \\
\text { plant at harvest }\end{array}$} \\
\hline & $2016 / 2017$ & $2017 / 2018$ & $2016 / 2017$ & $2017 / 2018$ & $2016 / 2017$ & $2017 / 2018$ \\
\hline Control & 0.230 & 0.248 & 0.10 & 0.28 & 221 & 210 \\
\hline Nitrogen (54kg/feddan) & 0.234 & 0.252 & 0.37 & 0.59 & 589 & 542 \\
\hline Nitrogen (90kg/feddan) & 0.239 & 0.261 & 0.69 & 0.53 & 680 & 640 \\
\hline Sissay $(810 \mathrm{~g} /$ feddan $)$ & 0.227 & 0.240 & 0.47 & 0.48 & 555 & 534 \\
\hline Micro nutrient (200ppm) & 0.232 & 0.235 & 0.18 & 0.39 & 527 & 464 \\
\hline $\begin{array}{l}\text { Nitrogen }(54 \mathrm{~kg} / \text { feddan })+\text { Micro } \\
\text { nutrients }(200 \mathrm{ppm})\end{array}$ & 0.237 & 0.258 & 0.41 & 0.57 & 644 & 625 \\
\hline $\begin{array}{l}\text { Nitrogen }(90 \mathrm{~kg} / \text { feddan })+\text { Micro } \\
\text { nutrients }(200 \mathrm{ppm})\end{array}$ & 0.241 & 0.266 & 1.01 & 0.78 & 726 & 786 \\
\hline $\begin{array}{l}\text { Sissay }(810 \mathrm{~g} / \text { feddan })+\text { Micro } \\
\text { nutrients(200ppm })\end{array}$ & 0.230 & 0.263 & 0.39 & 0.46 & 617 & 603 \\
\hline $\begin{array}{l}\text { Nitrogen }(54 \mathrm{~kg} / \text { feddan })+ \\
\text { Sissay }(810 \mathrm{~g} / \text { feddan })\end{array}$ & 0.240 & 0.262 & 1.02 & 1.23 & 794 & 812 \\
\hline $\begin{array}{l}\text { Nitrogen }(90 \mathrm{~kg} / \text { feddan })+ \\
\text { Sissay }(810 \mathrm{~g} / \text { feddan })\end{array}$ & 0.243 & 0.268 & 0.86 & 1.23 & 811 & 990 \\
\hline $\begin{array}{l}\text { Nitrogen( } 54 \mathrm{~kg} / \text { feddan })+\operatorname{Sissay}(810 \mathrm{~g} / \\
\text { feddan)+ Micro nutrients(200ppm) }\end{array}$ & 0.249 & 0.271 & 1.20 & 1.18 & 1070 & 1180 \\
\hline $\begin{array}{l}\text { Nitrogen }(90 \mathrm{~kg} / \mathrm{feddan})+\operatorname{Sissay}(810 \mathrm{~g} / \\
\text { feddan })+ \text { Micro nutrients }(200 \mathrm{ppm})\end{array}$ & 0.252 & 0.278 & 1.46 & 1.29 & 1081 & 1190 \\
\hline L.S.D 0.5 & 0.001 & 0.001 & 0.15 & 0.20 & 24.65 & 13.78 \\
\hline
\end{tabular}

Table 4. Average sucrose percentage ( $\%$ ) and sugar yield per plant ( $g$ ) of sugar beet at harvest time as affected by nitrogen, sissay and micro elements (Boron, Zinc and Manganese) fertilization treatment in 2016/2017 and 2017/2018 seasons.

\begin{tabular}{|c|c|c|c|c|}
\hline \multirow[t]{2}{*}{ Fertilization treatments } & \multicolumn{2}{|c|}{$\begin{array}{l}\text { Sucrose percentage }(\%) \text { a } \\
\text { harvest time }\end{array}$} & \multicolumn{2}{|c|}{$\begin{array}{l}\text { Sugar yield /plant (g) at } \\
\text { harvest time }\end{array}$} \\
\hline & 2016/2017 & $21017 / 2018$ & $2016 / 2017$ & $2017 / 2018$ \\
\hline Control & 20.39 & 20.49 & 45.00 & 43.03 \\
\hline Nitrogen $(54 \mathrm{~kg} / \mathrm{feddan})$ & 18.41 & 17.59 & 108.43 & 95.34 \\
\hline Nitrogen $(90 \mathrm{~kg} / \mathrm{feddan})$ & 17.09 & 17.04 & 112.79 & 109.06 \\
\hline $\operatorname{Sissay}(810 \mathrm{~g} /$ feddan $)$ & 18.54 & 18.71 & 102.90 & 99.91 \\
\hline Micro nutrient (200ppm) & 20.06 & 20.16 & 105.72 & 93.54 \\
\hline Nitrogen $(54 \mathrm{~kg} / \mathrm{feddan})+$ Micronutrients(200ppm) & 18.91 & 18.91 & 121.78 & 118.19 \\
\hline Nitrogen $(90 \mathrm{~kg} / \mathrm{feddan})+$ Micronutrients(200ppm) & 17.95 & 17.93 & 130.32 & 140.93 \\
\hline Sissay $(810 \mathrm{~g} /$ feddan) Micro nutrients(200ppm) & 18.78 & 18.68 & 115.87 & 112.64 \\
\hline Nitrogen (54kg/feddan)+ Sissay(810g/ feddan) & 18.19 & 18.97 & 144.43 & 154.04 \\
\hline Nitrogen $(90 \mathrm{~kg} /$ feddan $)+$ Sissay $(810 \mathrm{~g} /$ feddan $)$ & 18.87 & 17.77 & 153.04 & 175.92 \\
\hline $\begin{array}{l}\text { Nitrogen }(54 \mathrm{~kg} / \text { feddan })+\text { Sissay }(810 \mathrm{~g} / \text { feddan })+ \\
\quad \text { Micro nutrients(200ppm) }\end{array}$ & 18.85 & 19.40 & 201.69 & 228.92 \\
\hline $\begin{array}{l}\text { Nitrogen }(90 \mathrm{~kg} / \mathrm{feddan})+\text { Sissay }(810 \mathrm{~g} / \text { feddan })+ \\
\quad \text { Micro nutrients }(200 \mathrm{ppm})\end{array}$ & 18.69 & 19.30 & 202.04 & 229.67 \\
\hline L.S.D 0.5 & 0.87 & 0.94 & 0.65 & 0.82 \\
\hline
\end{tabular}




\section{ثاثير التسميد بالنانو على بنجر السكر \\ عبد المحيد محمد حسانين، عزب محمد عزب، محمد الأسمر الهواري *، ناضر ناير درويش

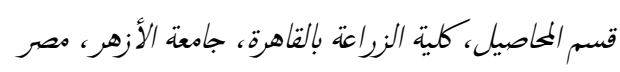

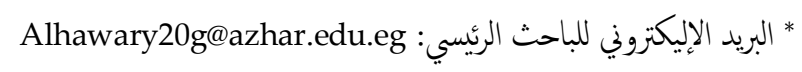

الملخص العربي

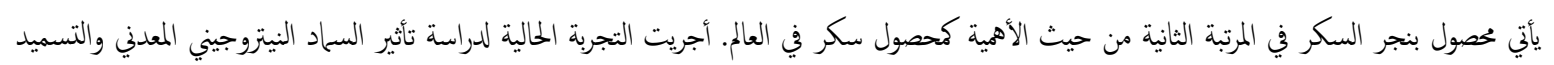

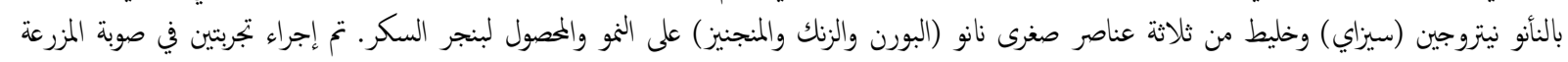

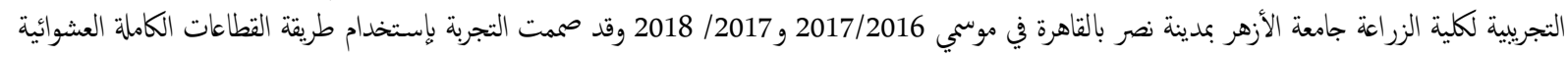

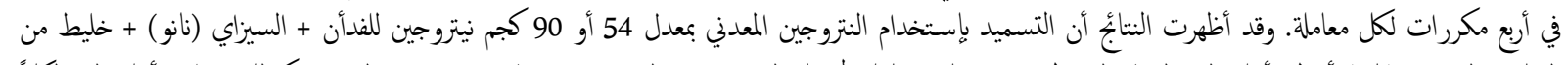

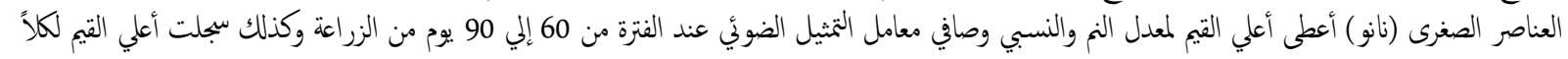

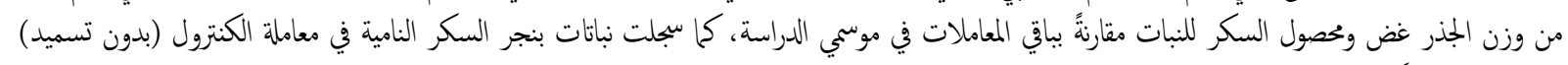

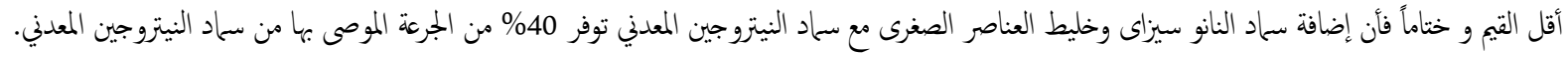

$$
\text { الكلمات المفتاحية: التسميد النانوي، بنجر السكر ، تسميد النيتروجين. }
$$

